\title{
PERAN KREDIT MODAL USAHA BAITUL MAAL WAT TAMWIL (BMT) DALAM PENINGKATAN PENDAPATAN RUMAH TANGGA MISKIN DESA MOTONG KECAMATAN UTAN
}

\author{
Didi Suwardi, SE.,M.Sc \\ Fitria PermataCita, SE.,ME
}

Fakultas Ekonomi dan Bisnis Universitas Teknologi Sumbawa (UTS)

\begin{abstract}
ABSTRAK
Rumusan masalah dalam penelitian ini adalah apakah pemberian kredit modal usaha BMT dapat berperan dalam meningkatkan pendapatan pada rumah tangga miskin di Desa Motong Kecamatan Utan. Tujuan pokok dalam penelitian ini adalah untuk menganalisis peran pemberian kredit usaha dalam meningkatkan pendapatan rumah tangga miskin setelah mendapatkan kredit modal usaha BMT di Desa Motong. Metode penelitian yang digunakan adalah metode Deskriptif. Penelitian ini di lakukan di BMT Desa Motong Kecamatan Utan Kabupaten Sumbawa. Jenis dan sumber data penelitian adalah data primer dan sekunder. Metode Pengumpulan Data menggunakan wawancara, kuesioner dan teknik dokmentasi. Populasi dan Sampel Jumlah populasi dalam penelitian ini yaitu sebanyak 168 nasabah BMT dan jumlah sampel berjumlah 63 nasabah BMT. Teknik analisis menggunakan rumus pendapatan dan uji statistik pangkat tanda wilcoxon.

Hasil penelitian menunjukkan bahwa Jumlah modal yang dimilki sebelum adanya kredit modal usaha berkisar antara Rp.350.000 s/d Rp.2.650.000/bulan dengan rata-rata sebesar Rp.1.177.778 dan jumlah pendapatan berkisar antara Rp.145.328 s/d Rp.6.462.624 dengan rata-rata Rp.2.600.779 dan jumlah modal yang dimiliki sesudah adanya kredit modal usaha berkisar antara Rp.850.000 s/d Rp.4.650.000/bulan dengan rata-rata sebesar Rp.2.755.556 jumlah pendapatan berkisar antara Rp.726.020 s/d Rp.9.058.756/bulan dengan rata-rata sebesar Rp.3.803.203, memiliki selisih sebesar Rp.1.202.424, hal ini disebabkan karena pendapatan sebelum adanya pemberian kredit modal usaha lebih kecil daripada pendapatan sesudah pemberian kredit modal usaha yang berarti pemberian kredit modal usaha BMT terhadap rumah tangga miskin dapat dikatakan meningkatkan pendapatan rumah tangga miskin. Dari hasil analisis pendapatan diketahui bahwa pendapatan usaha kecil sebelum adanya kredit modal usaha adalah Rp. 19.800.000 dengan rata-rata /responden sebesar Rp. 314.286 dan sesudah adanya kredit modal usaha di Desa Motong Kecamatan Utan Kabupaten Sumbawa Rp. 142.775.000, dengan rata-rata/responden sebesar Rp. 2.266.270, Artinya pendapatan meningkat sebesar 13,86\%. Pada uji statistik pangkat tanda wilcoxon menunjukkan keseluruhan nilai Asymp sig $0,000 \leq 0,05$ atau $Z_{\text {hitung }}$ sebesar -6.894 berada di daerah kritis $Z_{\text {tabel }} \leq 1,645$ atau $Z \geq-1,645$, sehingga Ho ditolak HI diterima. Konsekwensi dari HI diterima dan Ho ditolak berarti bahwa kedua variabel memiliki nilai median yang berbeda. Hipotesis yang menyatakan ada perbedaan pendapatan sesudah adanya modal kredit usaha, terbukti. Perbedaan tersebut disebabkan oleh faktor modal, pendapatan dan kredit modal usaha.
\end{abstract}

\section{Kata Kunci : Pendapatan, Sebelum dan Sesudah, Adanya Kredit}

\section{PENDAHULUAN \\ Latar Belakang}

Desa dan kemiskinan adalah dua hal yang tidak dapat dipisahkan, hal ini disebabkan karena wilayah pedesaan merupakan tempat bermukim bagi sebagian besar penduduk termasuk juga Kabupaten Sumbawa, Data BPS Kabupaten Sumbawa 2013 menunjukkan bahwa terdapat 157 desa yang terdistribusi pada 24 kecamatan (BPS Kabupaten Sumbawa 2014).
Kecamatan Utan adalah salah satu kecamatan dengan jumlah penduduk tertinggi ketiga setelah Kecamatan Sumbawa dan Kecamatan Alas, jika dilihat dari jumlah rumah tangganya maka Kecamatan Utan adalah kecamatan dengan jumlah rumah tangga tertinggi kedua setelah Kecamatan Sumbawa yang secara administratif merupakan pusat kabupaten. Apabila di breakdown per desa di Kecamatan Utan maka Desa Motong adalah desa yang memiliki jumlah Kepala Keluarga dan penduduk tertinggi (BPS Kabupaten 
Sumbawa 2012). Data Kecamatan Dalam Angka 2012 menunjukkan bahwa jumlah KK di Desa Motong pada tahun 2011 adalah 1.268 KK dengan jumlah penduduk sebanyak 4.619 jiwa dengan tingkat kesejahteraan penduduk yang masih rendah yang terindikasikan dengan dari jumlah KK Prasejahtera berjumlah 115 KK atau sekitar 9,1\% dari jumlah KK di Desa Motong. Masih banyakanya keluarga prasejahterah di Desa Motong disebabkan karena rendahnya pendapatan rumah tangga sehingga rentan dengan kemiskinan.

Suryawati (2005) mengidentifikasi penyebab kemiskinan khususnya di daerah perdesaan adalah karena keterbatasan aset yang dimiliki. Aset tersebut terbagi menjadi (1) Natural assets (2) Human assets (3) Physical assets (4) Financial assets (5) Social assets. Keterbatasan financial assets ini dapat diatasi dengan keberadaan Lembaga keuangan mikro, Ledgerwood (1999) dalam Lincolin Arsyad (2005) juga menegaskan bahwa tujuan lembaga keuangan mikro dalam pembangunan ekonomi salah satunya adalah mengurangi kemiskinan melalui dua pendekatan yaitu The Financial
System Approach dan The Poverty Lending Approach. Sementara itu menurut Martowijoyo (2002) dan Syukur (2006) gaung peran kredit mikro untuk menciptakan lapangan kerja mandiri guna mengurangi kemiskinan ini mulai berkembang luas di dunia sejak ikrar Microcredit Summit di washington DC.

Salah satu bentuk lembaga keuangan mikro adalah lembaga keuangan mikro syariah, Haryadi (2014) menyatakan bahwa lembaga keuangan mikro syariah yang paling populer saat ini adalah BMT. Secara nasional, jumlah BMT yang beroperasi di seluruh Indonesia berjumlah 3.500 unit. Salah satu BMT juga hadir ditengah-tengah masyarakat kecamatan Utan dalam rangka memberikan kontribusi besar dalam pemberdayaan ekonomi masyarakat sekitar, diantaranya melalui pembiayaan produktif bagi masayarakat umumnya dan rumah tangga miskin pada khususnya yang memiliki usaha. Gambar 1 menunjukkan jumlah anggota nasabah BMT Unit Utan Kecamatan Utan. Gambar 1 Data Jumlah Anggota Nasabah BMT Unit Utan Kecamatan Utan

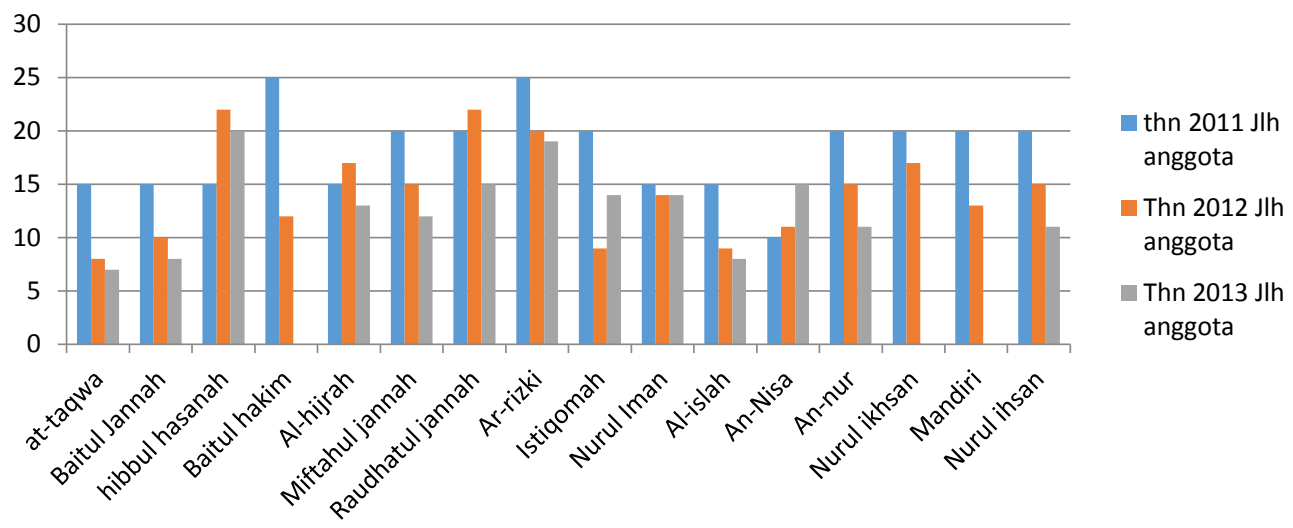

Sumber: Baitul Maal wat Tamwil (BMT) Kecamatan Utan

Gambar 1 menunjukkan jumlah nasabah sekaligus juga sebagai anggota pada BMT selama kurun waktu 2011 sampai 2013, seperti halnya lembaga keuangan lainnya kegiatan BMT dalah menghimpun dan menyalurkan dana dalam bentuk kredit modal usaha pada masyarakat termasuk pada rumah tangga miskin di Desa Motong Kecamatan Utan yang membutuhkan modal usaha.

\section{Tujuan Penelitian}

1. Berapa besar pendapatan rumah tangga miskin di Desa Motong Kecamatan Utan?

2. Apakah pemberian kredit modal usaha BMT berperan dalam meningkatkan pendapatan rumah tangga miskin di Desa Motong Kecamatan Utan?

\section{TINJAUN PUSTAKA \\ Kredit \\ Pengertian Kredit}

Menurut UU No. 7 Tahun 1992 sebagaimana telah diubah menjadi UU No.10 Tahun 1998 tentang Perbankan, disebutkan bahwa "kredit adalah penyediaan uang tagihan atau yang dapat dipersamakan dengan itu, berdasarkan persetujuan atau kesepakatan pinjaman antara bank dengan pihak lain yang mewajibkan pihak peminjam untuk melunasi utangnya setelah jangka waktu tertentu dengan 
jumlah bunga, imbalan atau bagi hasil keuntungan".

Hasibuan (2005) Kredit adalah semua jenis pinjaman yang harus dibayar kembali bersama bunganya oleh peminjaman sesuai dengan perjanjian yang telah disepakati.

\section{Jenis - Jenis Kredit}

Kasmir (2003), jenis kredit atas dasar tujuan penggunaan dananya oleh debitur dapat dibedakan sebagai berikut : (a) Kredit Modal Kerja (Working Capital) (b) Kredit Investasi (Investment) (c) Kredit Konsumsi. Masih menurut Kasmir ditinjau dari segi sektor usaha kredit terdiri dari: (a) Kredit pertanian, (b) Kredit pertenakan, (c) Kredit industri, (d) Kredit pendidikan, (e) Kredit profesi, (f) Kredit perumahan,

\section{Fungsi dan Manfaat Kredit}

Firdaus (2004) menjelaskan Fungsi kredit pada dasarnya ialah pemenuhan jasa untuk melayani kebutuhan masyarakat dalam rangka mendorong dan melancarkan produksi, perdagangan dan konsumsi, sehingga pada akhirnya akan menaikkan pendapatan masyarakat.

Krisna Wijaya (2005) menyatakan bahwa, kaitan antara pemberdayaan kredit mikro dengan upaya pengentasan kemiskinan merupakan pintu masuk relatif mudah bagi orang yang akan menjadi pengusaha pemula. Jika pengusaha pemula ini tumbuh dan berkembang akan terentaskan karena menjadi pengusaha atau karena trickle down effect dari semakin banyaknya pengusaha mikro.

Marguiret Robinson (2000) juga menjelaskan bahwa pinjaman dalam bentuk micro credit merupakan salah satu upaya yang ampuh dalam menangani kemiskinan. Hal tersebut didasarkan bahwa pada masyarakat miskin sebenarnya terdapat perbedaan klasifikasi diantara mereka, yang mencakup: pertama, masyarakat yang sangat miskin (the extreme poor) yakni mereka yang tidak berpenghasilan dan tidak memiliki kegiatan produktif, kedua, masyarakat yang dikategorikan miskin namun memiliki kegiatan ekonomi (economically active working poor), dan ketiga, masyarakat yang berpenghasilan rendah (lower income) yakni mereka yang memiliki penghasilan meskipun tidak banyak.

Manfaat lainnya dari kredit yang diberikan oleh lembaga keuangan yang memiliki fungsi sebagai intermediasi dalam aktifitas suatu perekonomian adalah memberi keuntungan usaha dengan adanya tambahan modal dan berkembangnya usaha. Kondisi ini dipertegas oleh Yoko (2015) dalam Adistiar (2015) yang menyatakan bahwa keberadaan dan pertumbuhan BMT di Kabupaten Lampung Tengah memiliki pengaruh yang positif dalam meningkatkan pendapatan petani melalui fasilitas pembiayaan (kredit) bagi petani.

\section{Baitul Maal wat Tamwil (BMT)}

Nasution (1992) dalam Anwar (2012) menyatakan bahwa istilah Baitul Mal wat Tamwil berasal dari bahasa arab yang terdiri dua suku kata yaitu bayt al-mal dan bayt altamwil. Bayt al-mal berasal dari kata bayt dan al-mal. Bayt artinya bangunan atau rumah, sedangkan al-mal berarti harta benda atau kekayaan. Jadi, secara harfiyah bayt al-mal berarti rumah harta atau kekayaan. Kata bayt almal biasa diartikan sebagai perbendaharaan (umum atau negara). Sedangkan dari segi istilah fiqih bayt al-mal adalah suatu lembaga atau badan yang bertugas untuk mengurusi kekayaan negara terutama keuangan, baik yang berkenaan dengan pemasukan dan pengelolaan, maupun yang berhubungan dengan masalah pengeluaran dan lain-lain. Sedangkan bayt altamwil berarti rumah penyimpanan harta milik pribadi yang dikelola oleh suatu lembaga.

Lebih lanjut Aziz (2004) dalam Anwar (2012) menjelaskan BMT adalah lembaga keuangan mikro yang dioperasikan dengan prinsip bagi hasil, menumbuhkembangkan bisnis usaha mikro dan kecil, dengan tujuan meningkatkan derajat dan martabat serta membela kaum fakir miskin.

Sementara itu Buchori (2012), menjelaskan bahwa BMT dirancang sebagai lembaga ekonomi rakyat, yang secara konsepsi dan secara nyata lebih fokus kepada masyarakat bawah, yang miskin dan nyaris miskin. Agenda kegiatannya yang utama adalah pengembangan usaha mikro dan usaha kecil, terutama melalui bantuan permodalan. Untuk melancarkan usaha pembiayaan tersebut, maka BMT berupaya menghimpun dana, yang terutama sekali berasal dari masyarakat lokal di sekitarnya.

\section{Pendapatan}

Sukirno (2004) menjelaskan pendapatan adalah jumlah penghasilan yang diterima oleh penduduk atas prestasi kerjanya selama satu periode tertentu, baik harian, mingguan, bulanan ataupun 
tahunan.Pendapatan itu berbeda dengan penerimaan.

Sementara itu, Soekartawi (2011) membedakan pendapatan rumah tangga di pedesan yang terbagi atas tiga kelompok, yaitu : (a) Pendapatan dari usaha bercocok tanam padi, (b) Pendapatan dari usaha bercocok tanam padi, palawija, dan kagiatan pertanian lainnya. (c) Pendapatan yang diperoleh dari seluruh kegiatan, termasuk sumber-sumber mata pencaharian di luar bidang pertanian.

\section{Kemiskinan}

\section{Pengertian dan Penyebab Kemiskinan}

Chamber (1987) dalam Rudi (2013) mendefinisikan dua macam situasi kemiskinan: pertama, kemiskinan yang disebabkan oleh keadaan yang jauh terpencil atau tidak memadai sumber daya, atau karena kedua-duanya sementara kedua kemiskinan merupakan suatu kedaan masyarakat yang didalamnya terdapat ketimpangan yang mencolok antara orang kaya dan orang miskin.

Lebih lanjut Sharp, et al (1996) dalam Mudrajad Kuncoro (2004) mengidentifikasi penyebab kemiskinan di pandang dari sisi ekonomi. Pertama, secara mikro, kemiskinan muncul karena adanya ketidaksamaan pola kepemilikan sumber daya. Kedua, kemiskinan muncul akibat perbedaan dalam kualitas sumber daya manusia. Ketiga, kemiskinan muncul akibat perbedaan akses dalam modal.

\section{Indikator Kemiskinan}

Indikator kemiskinan umumnya menggunakan kriteria garis kemiskinan (poverty line), Berikut ini akan diuraikan beberapa kriteria garis kemiskinan menurut Mudrajad Kuncoro (2004): (a) Garis Kemiskinan BPS, (b) Garis Kemiskinan Sajogyo, (c) Garis Kemiskinan Esmara

\section{METODE PENELITIAN \\ Teknik Pengumpulan Data}

Proses pengumpulan data dalam penelitian ini menggunakan teknik pengumpulan data dilakukan dengan teknik survei, yaitu dengan mengumpulkan data dari sejumlah individu (unit sampling) dalam waktu yang bersamaan untuk menggambarkan keadaan populasi dengan menggunakan daftar pertanyaan (quisioneir) terstruktur yang telah dipersiapkan sebelumnya.

\section{Analisis Data}

Analisis Pendapatan rumah tangga menggunakan rumus sebagai berikut Sukirno (2004):

$\mathrm{i}=\mathrm{TR}-\mathrm{TC} \ldots \ldots$

Dimana :

$\mathrm{i}=$ Pendapatan Bersih (Net Income); TR = Penerimaan Total Selama 1 Bulan ; $\mathrm{TC}=$ Biaya Total Selama 1 Bulan

Analisis peran dari kredit modal usaha BMT terhadap pendapatan rumah tangga miskin menggunakan statistik non parametik yaitu uji statistik pangkat tanda Wilcoxon. Dasar pengambilan keputusan adalah sebagai berikut, Tim Pelatihan Analisis Statistik (2008) :

$$
z=\frac{\mathrm{T}-\left[\frac{1}{4 \mathrm{~N}(\mathrm{~N}-1)}\right]}{\sqrt{\frac{1}{24 \mathrm{~N}(\mathrm{~N}+1)(2 \mathrm{~N}+1)}}}
$$

Dimana :

$\mathrm{N}=$ Banyak data yang berubah setelah diberi perlakuan yang berbeda; $\mathrm{T}=$ Jumlah ranking dari nilai selisih yang negatif (apabila banyaknya selisih yang positif lebih banyak dari banyaknya selisih negatif). Dan Jumlah ranking dari nilai selisih positif (apabila banyaknya selisih yang negatif lebih banyak dari banyaknya selisih positif).

$\mathrm{H} 0=0$ Tidak ada perbedaan variabel yang diuji sebelum dan sesudah memperoleh pinjaman kredit modal usaha dari BMT Unit Utan Kecamatan Utan.

$\mathrm{H} 1 \neq \quad 0$ Ada beda variabel yang diuji antara sebelum dan sesudah memperoleh pinjaman dari BMT unit Utan Kecamatan Utan.

Jika probabilitas (p) > 0,05 H0 diterima, jika probabilitas $(\mathrm{p})<0,05$ maka $\mathrm{H} 1$ diterima. Signifikansi penelitian ini akan membandingkan $\mathrm{Z}$ tabel dan $\mathrm{Z}$ hitung.

\section{HASIL DAN PEMBAHASAN Pendapatan Sebelum Adanya Kredit Modal Usaha}

Kisaran pendapatan rumah tangga miskin sebelum adanya kredit modal usaha BMT berkisar antara Rp. 145.328 - Rp. 6.462.624, dengan rata-rata Rp. 2.600.779. Besar pendapatan bersih usaha kecil sebelum adanya kredit modal usaha di Desa Motong Kecamatan Utan adalah Rp. 163.929.056, dengan rata-rata per responden adalah sebesar Rp. 2.602.049.

\section{Pendapatan Sesudah Adanya Kredit Modal Usaha}

Kisaran pendapatan rumah tangga miskin sesudah adanya kredit modal usaha BMT 
berkisar antara Rp.726.020-Rp.9.058.756 dengan rata-rata Rp.3.803.203 serta selisih ratarata yang diperoleh sebesar Rp1.202.424 atau meningkat sebesar $18,78 \%$. Dari perbedaan pendapatan tersebut dapat disimpulkan bahwa dengan adanya pemberian kredit modal usaha BMT terhadap rumah tangga miskin dapat dikatakan meningkatkan pendapatan rumah tangga miskin. Besar pendapatan bersih dari usaha yang diperoleh sesudah adanya kredit modal usaha adalah sebesar Rp. 237.287.245, dengan rata-rata per responden adalah sebesar Rp. 3.766.464, hasil pendapatan bersih tersebut dapat mempengaruhi tingkat kesejahteraan dari masyarakat rumah tangga miskin itu sendiri.

Hasil dari penelitian ini yaitu pemberian kredit dalam hal meningkatan pendapatan yang diperoleh keluarga miskin dengan adanya bantuan modal usaha BMT berkisar Rp.500.000 s/d Rp.2.000.000, yang dapat mencukupi kebutuhan usaha yang dijalankan oleh rumah tangga miskin. Dalam pemanfaatan modal usaha tersebut tingkat hari kerja untuk berjualan bertambah artinya masyarakat rumah tangga miskin mempunyai peluang usaha sangat besar, dan disertai dengan adanya penetapan bagi hasil yang pengukurannya berdasarkan kesepakatan antara lembaga BMT dan nasabah peminjam kredit modal usaha yang terbilang murah, tidak membebani dan sesuai dengan tingkat hasil keuntungan/kerugian dari proses usaha yang dijalankan oleh rumah tangga miskin.

\section{Analisa Peran Kredit Modal Usaha Dalam Meningkatkan Pendapatan Dengan Menggunakan Uji Wilcoxon}

Tabel Wilcoxon Signed Ranks Test

\begin{tabular}{|l|l|}
\hline & $\begin{array}{l}\text { Sesudah Adanya } \\
\text { Kredt Modal Usaha } \\
\text { - Sebelum Adanya } \\
\text { Kredit Modal usaha }\end{array}$ \\
\hline$Z$ & $-6.894^{\text {a }}$ \\
\hline $\begin{array}{l}\text { Asymp. Sig. } \\
\text { (2-tailed) }\end{array}$ & .000 \\
\hline
\end{tabular}

\section{a. Based on}

negative

ranks.

b. Wilcoxon

Signed

Ranks Test

Sumber: Data Primer diolah Tahun 2014
Pada tabel di atas menunjukkan keseluruhan nilai Asymp sig $0,000 \leq 0,05$ atau $Z_{\text {hitung }}$ sebesar -6.894 berada di daerah kritis $Z_{\text {tabel }} \leq 1,645$ atau $\mathrm{Z} \geq-1,645$, sehingga Ho ditolak HI diterima. Konsekwensi dari HI diterima dan Ho ditolak berarti bahwa kedua variabel memiliki nilai median yang berbeda. Hipotesis yang menyatakan ada perbedaan pendapatan sesudah adanya modal kredit usaha, terbukti. Perbedaan tersebut disebabkan oleh faktor modal, pendapatan dan kredit modal usaha.

\section{SIMPULAN DAN SARAN}

\section{Simpulan}

1. Pendapatan usaha rumah tangga miskin sebelum adanya kredit modal usaha adalah Rp. $\quad 19.800 .000$ dengan rata-rata /responden sebesar Rp. 314.286 dan sesudah adanya kredit modal usaha di Desa Motong Rp. 142.775.000, dengan rata-rata/responden sebesar Rp. 2.266.270, Artinya pendapatan meningkat sebesar 13,86\%.

2. Pada uji statistik pangkat tanda wilcoxon menunjukkan keseluruhan nilai Asymp sig $0,000 \leq 0,05$ atau $Z_{\text {hitung }}$ sebesar -6.894 berada di daerah kritis $\mathrm{Z}_{\text {tabel }} \leq 1,645$ atau $\mathrm{Z}$ $\geq-1,645$, sehingga Ho ditolak HI diterima. Konsekwensi dari HI diterima dan Ho ditolak berarti bahwa kedua variabel memiliki nilai median yang berbeda. Hipotesis yang menyatakan ada perbedaan pendapatan sesudah adanya modal kredit usaha, terbukti. Perbedaan tersebut disebabkan oleh faktor modal, pendapatan dan kredit modal usaha

Saran

1. BMT unit Desa Motong sebaiknya memperhatikan faktor-faktor yang mempengaruhi perputaran modal usaha antara lain perputaran kas, perputaran piutang dan perputaran persediaan.

2. Disarankan kepada penelitian selanjutnya untuk mengkaji dan memperluas cakupan penelitiannya baik dari sisi variabel, responden, metode maupun tempat penelitiannya tentang Peran kredit Modal Usaha BMT Dalam Peningkatan Pendapatan Rumah Tangga Miskin Di Desa Motong Kecamatan Utan.

\section{DAFTAR PUSTAKA}

Anonim_ 2012. Kecamatan Dalam Angka Tahun 2012. Sumbawa : Badan 
Pusat Statistik.

Anwar, Khoirul, Moch. 2012. Operasional Baitul Maal Wat Tamwil Dalam pemberdayaan Ekonomi Umat di Kabupaten Sidoarjo. Jurnal Akuntasi Akrual.

http://fe.unesa.ac.id/ojs/index.php/akrl.

Diakses pada tanggal 25 Maret 2016

Arsyad, Lincolin. 2005. An Assessment of Microfinance Institution Perfromance: The Importance of Institutional Environment. Gadjah Mada International Journal of Business 7(3): 391 - 427.

Buchori NS. 2012. Koperasi Syariah. Tangerang Selatan: Pustaka Aufa Media.

Firdaus, H.R. 2004. Manajemen Perkreditan Bank Umum: Teori, Masalah, Kebijakan dan Aplikasi. Alfabeta, Bandung.

Haryadi, Didi. (2014). Masa Depan BMT Makin Cerah. www.inilahkoran.com. Diakses pada tanggal 25 Maret 2016

Hasibuan, Melayu S.P. 2005. Dasar Dasar Perbankan. Bumi Aksara. Jakarta.

Kasmir. 2003. Manajemen Perbankan. PT. Raja Grafindo Persada Jakarta.

Kuncoro, Mudrajad. 2004. Otonomi Dan Pembangunan Daerah: Reformasi, Perencanaan, Strategi, dan peluang, Erlangga. Jakarta.

Wijaya, Krisna. 2005. Kredit Mikro Bukan Hibah. Harian Kompas, Selasa, 1 Maret 2005.

Marquerite S. Robinson. 2002. Beberapa Strategi yang Berhasil Untuk Mengembangkan Bank Pedesaan: Pengalaman dengan Bank Rakyat Indonesia 1970 - 1990, dalam Bunga Rampai Pembiayaan Pertanian Pedesaan, Sugianto (Ed.), Penerbit Institut Bankir Indonesia, Jakarta.

Martowijoyo, S. 2002. Dampak Pemberlakukan Sistem bank Perkreditan Rakyat Terhadap Kinerja Lembaga perdesaan. Artikel-Th.1 No-5 . Jurnal Ekonomi

Rakyat.www.ekonomirakyat.org.

Diakses pada tanggal 20 Februari 2016.

Prayoga, Adistiar. 2015. Peran Islamic Microfinance Dalam Upaya Pengentasan Kemiskinan Pada Masyarakat Profesi Petani di Perdesaan Indonesia.

https://adistiarprayoga.wordpress.com/ 2015/07/01/peran-islamic-

microfinance-dalam-upaya- pengentasan-kemiskinan-pada-

masyarakat-profesi-petani-di-

perdesaan-indonesia. Diakses pada tanggal 20 Februari 2016.

Soekartawi Dkk, 2011. Ilmu Usaha Tani. Jakarta :UI press

Sukirno, S. 2004. Pengantar Teori Mikro Ekonomi. Raja Grafindo Persada, Jakarta.

Suryawati, C. 2005. Memahami Kemiskinan Secara Multidimensi. Jurnal Agroekonomi Vol. 08(03) September 2005

Syaf, Rudi dkk. 2013. Faktor-Faktor yang Mempengaruhi Pendapatan Rumah tangga Miskin di Sekitar Taman Nasional Bukit Dua Belas (Studi Kasus Desa-Desa Penyangga TNBD di Kecamatan Maro Sebo Ulu, Kabupaten Batang Hari). Jurnal Perspektif Pembiayaan dan Pembangunan Daerah Vol. 1 No. 2, Oktober 2013.

Syukur, M. 2006. Membangun Lembaga Keuangan Mikro (LKM) Pertanian Yang Berkelanjutan: Sebuah Pengalaman Lapangan. Warta Prima Tani . Volume 1 Nomor 1. Balai Besar Pengkajian dan Pengembangan Teknologi Pertanian.

Tim Pelatihan Analisis Statistik. 2008. Materi Pelatihan Analisis Statistik (PAS). Program Magister dan Doktor Ilmu Ekonomi Fakultas Ekonomika dan Bisnis UGM. Tidak dipublikasikan. 
JURNAL TAMBORA Vol 2 No 3 Desember 2017 
JURNAL TAMBORA Vol 2 No 3 Desember 2017 